\title{
Two New Milestones from the Territory of Juliopolis
}

\author{
Fatma AVCU*
}

In his Roman Roads and Milestones of Asia Minor (RRMAM) project ${ }^{1}$ D. French published 3 milestones found in the Çayırhan vicinity dating from the Caracallan period ${ }^{2}$. In the first fascicule of RRMAM, The Pilgrim's Road, D. French wrote that in 1972 while he and his family were picnicking, he came across a well preserved Roman paved road at a short distance from Nallihan and found 2 milestones, each of them in situ. He also narrated that in his next visit he found a third, also in situ, and the remains of the Roman road were traced as far as ca. $20 \mathrm{~km}$ west of Ankara ${ }^{3}$. On the matter of the settlement's location on the Pilgrim's Road ${ }^{4}$, Juliopolis was first localised wrongly to a place, ca. $15 \mathrm{~km}$ south of Nallihan and north of Emremsultan ${ }^{5}$, and this localization was followed by W. M. Ramsay and J. G. C. Anderson ${ }^{6}$ and accepted until the ruins of Eskişehir in Çayırhan were identified as Juliopolis by D. French, based upon those 3 milestones ${ }^{7}$. The milestones, which give Juliopolis as caput viae, confirm the location of Juliopolis and provide indirectly indication concerning the location of the other settlements ${ }^{8}$. A distance from Juliopolis is given in these milestones inscriptions. In French 2013, no. 92 (Çayırhan1) records restored $9 \mathrm{mp}$ (milia passuum) $(\mathrm{ca} .=13,2 \mathrm{~km})$, no. 93 (Çayırhan2) records $5 \mathrm{mp}(\mathrm{ca} .=7,4 \mathrm{~km})$ and no. 94 (Çayırhan3) records $8 \mathrm{mp}(\mathrm{ca} .=11,8 \mathrm{~km})$ from Juliopolis. In addition, another milestone, also

\footnotetext{
* Arş. Gör. Dr. Fatma Avcu, Akdeniz Üniversitesi, Edebiyat Fakültesi, Eskiçağ Dilleri ve Kültürleri Bölümü 07058 Antalya (fatmaavcu@akdeniz.edu.tr; https://orcid.org/0000-0002-9196-239X).

I thank Prof. Dr. Fatih Onur, to whom Mustafa Metin (Ankara) gave the details of the milestones and who asked me to publish it. There was no chance to see in person the milestones, due to several restrictions including travel in the Covid-19 pandemic. We plan to see the milestones, especially the second, to see if a better reading is possible when travel again proves possible. For improving the English I thank T. M. P. Duggan.

${ }^{1}$ For detail information see https://biaa.ac.uk/publications/item/name/electronic-monographs (date accessed 05.03.2020).

${ }^{2}$ French 1981, 36-37; 1988, 48-49; 2013, 144-146, nos. 92-94.

${ }^{3}$ French 1981, 33.

${ }^{4}$ For detailed information concerning the Pilgrim's Road see French 1981, 13-32a.

${ }^{5}$ Lejean 1869, 63-64. He followed the route given by Kiepert, see Kiepert 1864, 312-315 and 322-323; cf. Mannert 1802, 68-75 and 107; Onur 2014, 71.

${ }^{6}$ Ramsay 1890, 241; Anderson 1897-8, 68; Crowfoot - Anderson 1899, 69-70.

${ }^{7}$ This identification was confirmed by coins, bearing the name of the city, found at Çayırhan, see Arslan et al. 2011, 271-273.

${ }^{8}$ Other ancient settlements, given on the route from or to Juliopolis, were mentioned on itineraries because this region is on the ancient major route between Constantinople and Ancyra. Within this context the certain localization of Juliopolis is important for the localization of the other sites. Various routes, e.g. from Dastana to Juliopolis or from Juliopolis to Lagina, are mentioned in itineraries such as: Tabula Peutingeriana, Itinerarium Antonini, Itinerarium Burdigalense. For detailed information see Onur 2014, 67-68.
} 
from the Caracallan period, was found at Sobranköy, immediately to the east of Nallıhan and ca. $30 \mathrm{~km}$ northwest of Çayırhan?.

\section{New milestones}

Two milestones are reported by museum staff. Both milestones were found in the west-northwest territories of Çayırhan. But the full text of only one of them is presented here, since it is almost impossible to make a conclusive investigation from the photos of second milestone. The photographs and measurements of the following inscription were provided by Mustafa Metin from the Museum of Anatolian Civilizations and sent to Fatih Onur, who had conducted an epigraphic project in and around Nallıhan and Çayırhan with a team, of which I was a member ${ }^{10}$. One of the milestones carries almost the same text as the other three already published by D. French (see below).

No. 1) Milestone from the Caracallan Period (Figs. 3-4)

Find-Spot: On the north-western borders of Çayırhan District of Nallıhan, by the modern road to Atça after ca. $1.2 \mathrm{~km}$ to the north from the detour on the main road between Nallihan and Ankara. Secured from an illegal excavation. Cylindrical grey limestone milestone. Small broken part at the edge of the upper side. The inscription of 11 lines is well preserved. Inv. No.: - ; H.: $270 \mathrm{~cm}$; Diam.: $65 \mathrm{~cm}$. Lh.: $5 \mathrm{~cm}$. Read from photo.

$\mathrm{B}$ (ona) [F(ortuna)]

2 Imp(erator) Caes(ar) M(arcus) Aurelius

Antoninus Pius Aug(ustus)

4 Parthicus maximus

Britannicus maximus

6 Germanicus maximus

pontifex maximus

8 tribunic(ia) potest(ate) XVIIII

Imp(erator) III co(n)s(ul) IIII $\mathrm{P}($ ater $) \mathrm{P}($ atriae $)$ proco(n)s(ul)

10 A Iuliopoli

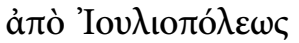

VII

$\mathrm{Z}$

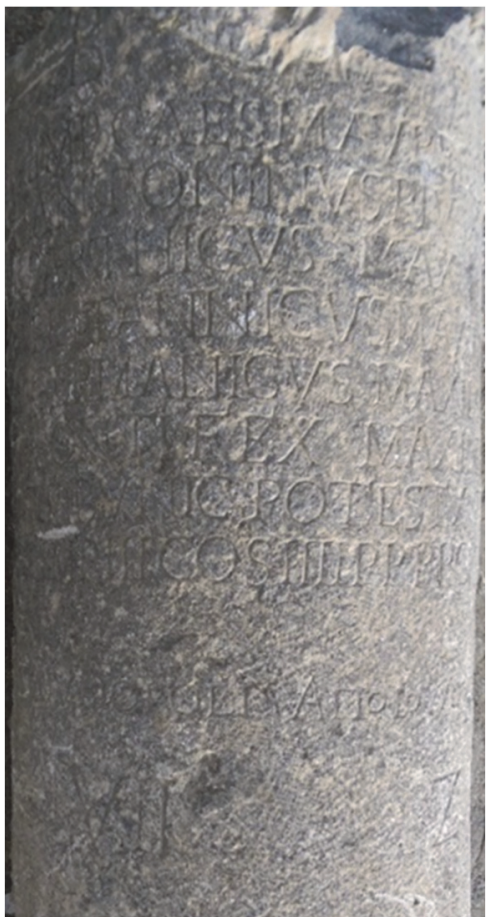

With good fortune. Imperator Caesar Marcus Aurelius Antoninus Pius Augustus, Parthicus maximus, Brittanicus maximus, Germanicus Maximus, pontifex maximus, in the $19^{\text {th }}$ tribunician power, imperator for the $3^{\text {rd }}$ time, consul for the $4^{\text {th }}$ time, father of the country, proconsul.

From Juliopolis 7 (miles). From Iouliopolis 7 (miles).

\footnotetext{
${ }^{9}$ Marek 2000, 131, fn. 5; French 2013, 143, no. 91 (Sobran) see below for its text.

${ }^{10}$ For other results see Onur 2014; Onur (C.) 2014; Avcu - Doğan 2014; Avcu 2016; Doğan - Avcu 2018.
} 
Date: $215 / 216 \mathrm{AD}$

\section{No. 2) Fragmentary Milestone (Figs. 5-6)}

Find-Spot: The same as No. 1. Secured from an illegal excavation. No measurement is available. Cylindrical grey limestone milestone. Broken from upper and down side. The inscription on the shaft is very worn, mostly illegible. The letters given below are mostly not secure. No further reading or restorations can be done.
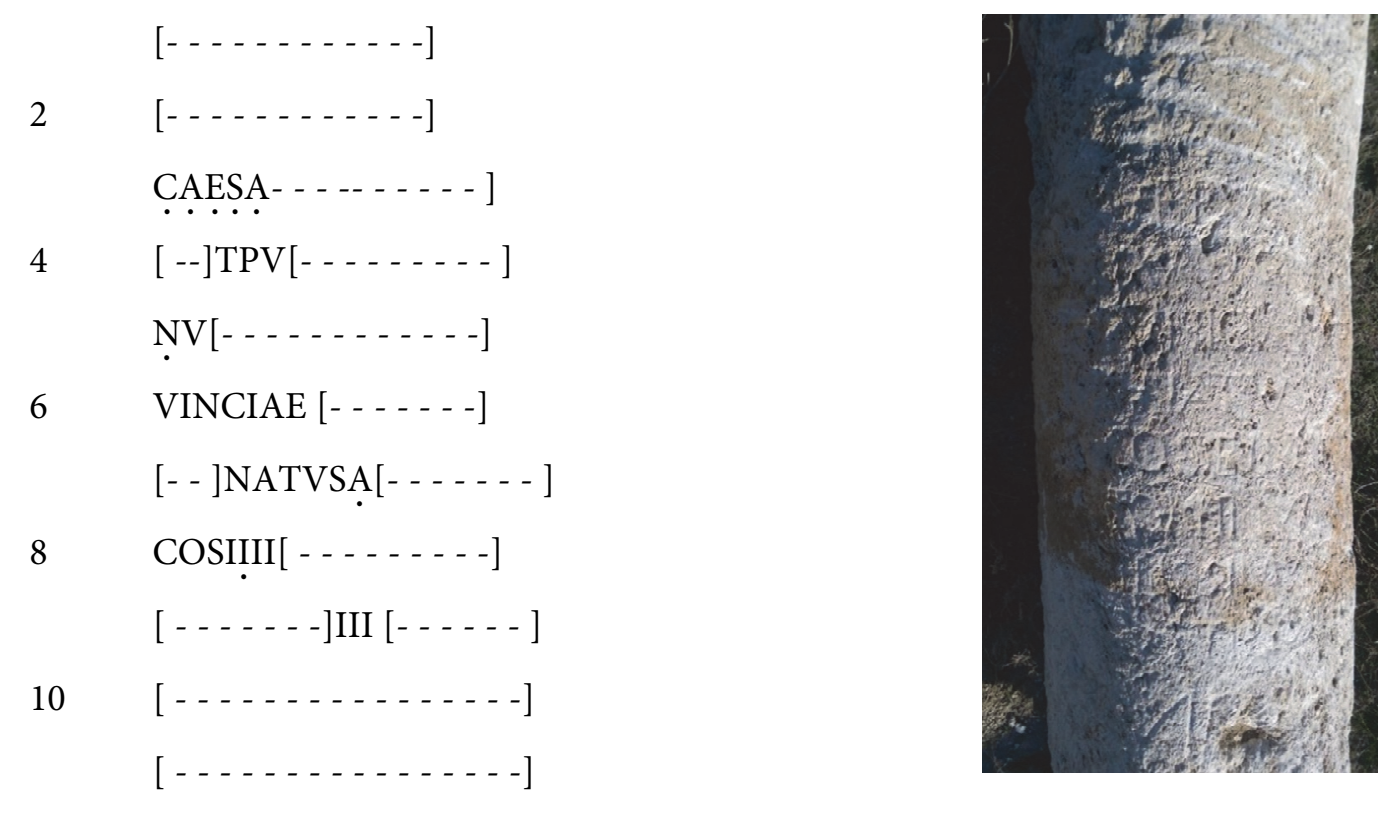

12

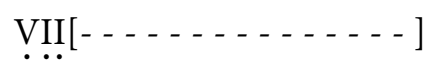

No. 92 (Çayırhan1), recorded 9 miles (restored) from Juliopolis, was found on the north side of the Roman road, ca. 1,60 km west of the point where the road to Atça and Nallıgölcük crosses the Roman road. No. 93 (Çayırhan2) of French, recorded $5 \mathrm{mp}$ (ca. 7,4 km) from Juliopolis, was found $30 \mathrm{~m}$ east of the point where the Roman road crosses the modern road from Ankara to Nallihan, and ca. $20 \mathrm{~m}$ south of the modern road, on the north side of the Roman road ${ }^{11}$. The new milestones are located between No. 92 and 93 of French and were found ca. 1,2 km north of the modern Nallıhan road on the way to Atça (see Figs. 1-2). $7 \mathrm{mp}$ (ca. 10,3 km) in no. 1 above, fits the distance to Juliopolis, and the location of the new milestones is at a distance of ca. $3 \mathrm{~km}$ to the east of no. 92 (Çayırhan1) of French. Apparently, there was another milestone with the distance of $8 \mathrm{mp}$ between these two. The same goes for no. 93 (Çayırhan2) of French, as its location is ca. $3 \mathrm{~km}$ to the west, leaving space for another milestone with the distance of $6 \mathrm{mp}$. Therefore, it was most likely found in situ or close to the in situ spot. It provides further evidence for the course of the ancient route from Juliopolis. No. 94 (Çayırhan3), recorded 8 miles from Juliopolis, was found ca. $15 \mathrm{~m}$ west of the Kuruvadi and $1.702 \mathrm{~km}$ north of a path from Kayabükü çiftlik to Kösebükü çiftlik, which is on the way to Ankyra ${ }^{12}$.

\footnotetext{
${ }^{11}$ French 1981, 37; 2013, 145.

${ }^{12}$ French 1981, 37; 2013, 146.
} 
Caracalla's route, across Asia Minor on his way to the Parthian war in 214/215 AD, has been discussed by some scholars. A description by a citizen of Prusias ad Hypium as $\pi \alpha \rho a \pi \dot{\varepsilon} \mu \psi \alpha \varsigma$ for the armies of both Severus and of Caracalla caused some to assume that like his father, Caracalla marched to the east through Bithynia, Galatia and Cappadocia ${ }^{13}$. On the other hand, this assumption was seen as inadequate due to the idea that the erection of a statue, honouring a citizen and granting the neocories in person did not indicate a visit ${ }^{14}$. There is no certainty for the route taken by the Emperor, nor any implication on the milestones that he marched through Juliopolis to Ancyra, however, as proposed by D. French ${ }^{15}$, he might have used the Juliopolian way to arrive at Ancyra, when he marched to the east.

The five milestones found within the territory of Juliopolis from west to east are as follow:

See above fn. 9. Imp. Cae[s . M. Aureli]us / Antoni[nus Pius] Aug. / Parthicu[s maxi]mus / Brita[nnicus maxi]mus / G]erm[anicus maxi]mus / [Pontifex maxi]mus / [...............]

French 2013, [B(ona) F(ortuna)] $\mid$ Imp(erator) Caes(ar) M(arcus) 144, no. 92 (Ça-A]urellius |[Antoninus] Pius Aug(ustus)|[Parthic]us yırhan 1) maximus |[Britanni]cus maximus |[Germa]nicus maximus $\mid$ [pontifex] maximus |[tribuni]c(ia) pot(estate) XVIIII | [imp(erator) III co(n)s(ul)] IIII [p(ater) p(atriae)] proco $(n) s(u l) \mid$ [a Iuliop]o[li mil(ia) VIIII] /

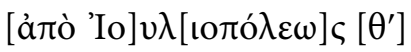

\section{New milestone. B(ona) [F(ortuna)] Imp(erator) Caes(ar) M(arcus)} Aurelius | Antoninus Pius Aug(ustus) | Parthicus maximus | Britannicus maximus | Germanicus maximus | pontifex maximus | tribunic(ia) potest(ate) XVIIII | Imp(erator) III co(n)s(ul) IIII P(ater) P(atriae)

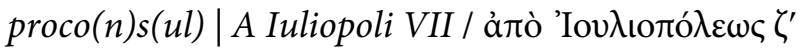

Found to the northwest of Juliopolis on the ancient course of the road leading from northwest.

Found to the northwest of Juliopolis on the ancient course of the road leading from northwest.

[9] $\mathrm{mp}=$ ca. $13,2 \mathrm{~km}$ from Juliopolis

Found to the northwest of Juliopolis on the ancient course of the road leading from northwest. $7 \mathrm{mp}=$ ca. $10,3 \mathrm{~km}$ from Juliopolis

Found to the west of Juliopolis on the ancient course of the road leading from northwest. pontifex maximus | tribunic(ia) potest(ate) XVIIII | imp(erator) III co(n)s(ul) IIII p(ater) p(atriae)

French 2013, B(ona) F(ortuna) $\mid \operatorname{Imp}$ (erator) Caes(ar) M(arcus) Au144-145, no. 93 rellius |Antoninus Pius Aug(ustus) | Parthicus maxi(Çayırhan 2) mus $\mid$ Britannicus maximus | Germanicus maximus $\mid$

${ }^{13}$ Magie 1950, 685, and n. 43; Levick 1967, 33; The given references for this assumption see. IGR III, no: 60, 62 and 1422 (for a festival named for Caracalla at Prusias); AE 1932, no: 49 (a milestone at Ancyra); see also Schwarz - Stauner 2007, 6-9.

${ }^{14}$ Drexler 1880; French 1981, 45. A. Johnston also criticized the way the possible evidence had been examined and provides a solution to the problem of the Caracalla's route, pointed out that for solving the problem, all the evidence, inscriptions, coins and literary sources, should be carefully scrutinized. She provides a list of the evidence and the suggested possible places for the route (Juliopolis is regarded as a presumable place). For detail, see Johnston 1983.

${ }^{15}$ French 1981, 45. 
$\operatorname{proco}(n) s(u l) \mid$ a Iuliopoli mil(ia) V/ ảंò

'Iovגıто́ $\lambda \varepsilon \omega \varsigma \varepsilon^{\prime}$

French 2013, [B(ona) F(ortuna)] Imp(erator) Ca[es(ar) M(arcus) 145, no. 94 (Ça- Aurellius] | Ant[oninus Pius Aug(ustus)] | Parthi[cus yırhan 3)

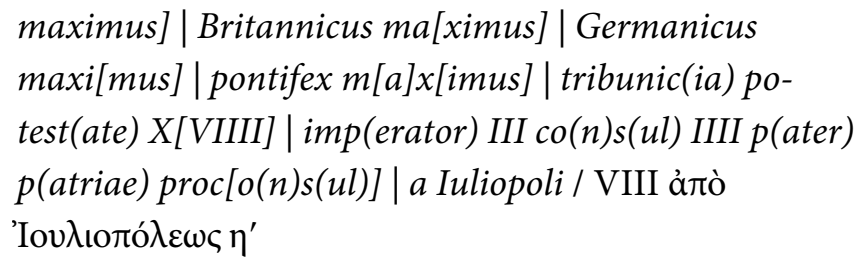

$5 \mathrm{mp}=$ ca. $7,4 \mathrm{~km}$ from Juliopolis

Found to the east of Juliopolis on the ancient course of the road to Ankyra. $8 \mathrm{mp}=$ ca. $11,8 \mathrm{~km}$ from Juliopolis

\section{Bibliography}

Anderson 1897-8

Arslan et al. 2011

Avcu - Doğan 2014

Avcu 2016

J. G. C. Anderson, Exploration in Asia Minor during 1898. First report, ABSA 4, 1897-8, 48-78.

M. Arslan - M. Metin - O. Cinemre - T. Çelik - M. Türkmen, Juliopolis Nekropolü 2010 Yılı Kazı Çalışmaları, 19. Müze Çalışmaları ve Kurtarma Kazıları Sempozyumu, Ankara 2011, 271-304.

F. Avcu - Y. Doğan, Epigraphic Research around Juliopolis II: New Inscriptions from Nallihan, Gephyra 11, 2014, 85-99.

F. Avcu, Nallıhan Çevresinden Yeni Yazıtlar: Sulpicii Ailesi, in: B. Takmer - E. Akdoğu Arca - N. Gökalp Özdil (edd.), Vir Doctus Anatolicus. Studies in memory of Sencer Şahin, İstanbul 2016, 116121.

Crowfoot - Anderson 1899 J. W. Crowfoot - J. G. C. Anderson, Exploration in Galatia cis Halym, The Journal of Hellenic Studies 19, 1899, 34-134 and 318.

Doğan - Avcu 2018

Y. Doğan - F. Avcu, Nallıhan ve Çevresinden Yeni Yazıtlar II, Olba 26, 2018, 403-429.

Drexler 1880

W. Drexler, Caracallas Zug nach dem Orient und der letzte Partherkrieg, Halle 1880.

French 1981

D. French, Roman Roads and Milestones of Asia Minor, Fasc. 1: Pilgrim's Road (BIAA Monograph. 3), Oxford 1981.

French 1988

D. French, Roman Roads and Milestones of Asia Minor, Fasc. 2, Part. 1: An Interim Catalogue of Milestones (BIAA Monograph. 9), 1988.

French 2013

D. French, Roman Roads and Milestones of Asia Minor Vol. 3: Milestones, Fasc. 3.4: Pontus et Bithynia (with Northern Galatia) (BIAA Electronic Monograph 4), London 2013. Link

French 2016

D. French, Roman Roads and Milestones of Asia Minor Vol. 3: Milestones, Fasc. 3.9, An Album of Maps (BIAA Electronic Monograph 9), London 2016. Link

Johnston 1983

A. Johnston, Caracalla's path: The Numismatic Evidence, Historia $32,1983,58-76$. 
Kiepert 1864

Lejean 1869

Levick 1967

Magie 1950

Mannert 1802

Marek 2000

Onur 2014

Onur (C.) 2014

Ramsay 1890

Schwarz - Stauner 2007

H. Kiepert, Beiträge zur inschriftlichen Topographie Kleinasiens, Monatsberichten d. Akad. (Aus dem Jahre 1863), 1864, 307-323.

G. Lejean, Excursion à la recherce de Gordium (Asie Mineure), Bulletin de la Société de géographie 5/17, 1869, 62-66.

B. Levick, Coins and Inscriptions of Colonia Comama, the Numismatic Chronicle 7, 1967, 29-35.

D. Magie, Roman Rule in Asia Minor, to the End of the Third Century After Christ, Princeton 1950.

K. Mannert, Geographie der Griechen und Römer, 6.3: Kleinasien, Nürnberg 1802.

C. Marek, Die höchste, beste, grösste, allmächtige Gott, EA 32, 2000, 129-146.

F. Onur, Epigraphic Research around Juliopolis I: A historical and Geographical Overview, Gephyra 11, 2014, 65-83.

C. (Arıkan) Onur, Epigraphic Research around Juliopolis III: Roman and Byzantine Inscriptions from Doğandere and Juliopolis, Gephyra 11, 2014, 101-113.

W. M. Ramsay, The Historical Geography of Asia Minor, London 1890.

H. Schwarz - K. Stauner, Die Parapompé des Kaisers und seines Heeres im nordwestlichen Kleinasien, Gephyra 7, 2007, 1-35.

\section{Iuliopolis Teritoryumundan İki Yeni Miltaşı}

Öz

$\mathrm{Bu}$ yazıda Nallıhan civarındaki Çayırhan'da bulunan iki yeni miltaşı tanıtılmaktadır. No. 1 RRMAM'da yayınlanan diğer 3 miltaşı ile tıpatıp benzerdir ve aynı bölgede bulunmuştur. Miltaşı Iulipolis'ten 7 milia passuum mesafe uzaklık vermektedir. Daha önce RRMAM'da yayımlanan miltaşlarından ilk ikisinin arasında konumlanmaktadır. Aynı yerinde ele geçen No. 2 ise hem kırık hem de yazıtın son derece yıpranmış olmasından dolayı sonuç verici bir okuma yapılamamıştır. Yazıtın çevirisi şu şekildedir:

İyi talihle! Büyük Parth, Britannia ve Germannia fatihi, başrahip, tribunicia potestas yetkisini 19 kez elinde bulunduran, 3 kez imparator olarak selamlanmış, 4 kez consul olan, vatanın babası ve proconsul Imparator Caesar Marcus Aurelius Antoninus Pius Augustus. Iuliopolis'ten 7 (mil).

Anahtar Sözcükler: Iuliopolis, Nallıhan, Çayırhan, Bithynia, Galatia, Roma Dönemi Miltaşları.

\section{Two New Milestones from the Territory of Juliopolis}

\section{Abstract}

This paper presents two new milestones, found at Çayırhan/Nallıhan, Ankara. No.1 is identical with and from same find spot as three other milestone's inscriptions published in RRMAM but records $7 \mathrm{mp}$ from Juliopolis. It was situated between the first two milestones, published in RRMAM. No.2, also found in the same place, is largely illegible and fragmentary, for this reason an adequate reading could not be provided.

Keywords: Juliopolis, Nallıhan, Çayırhan, Bithynia, Galatia, Roman Milestones. 


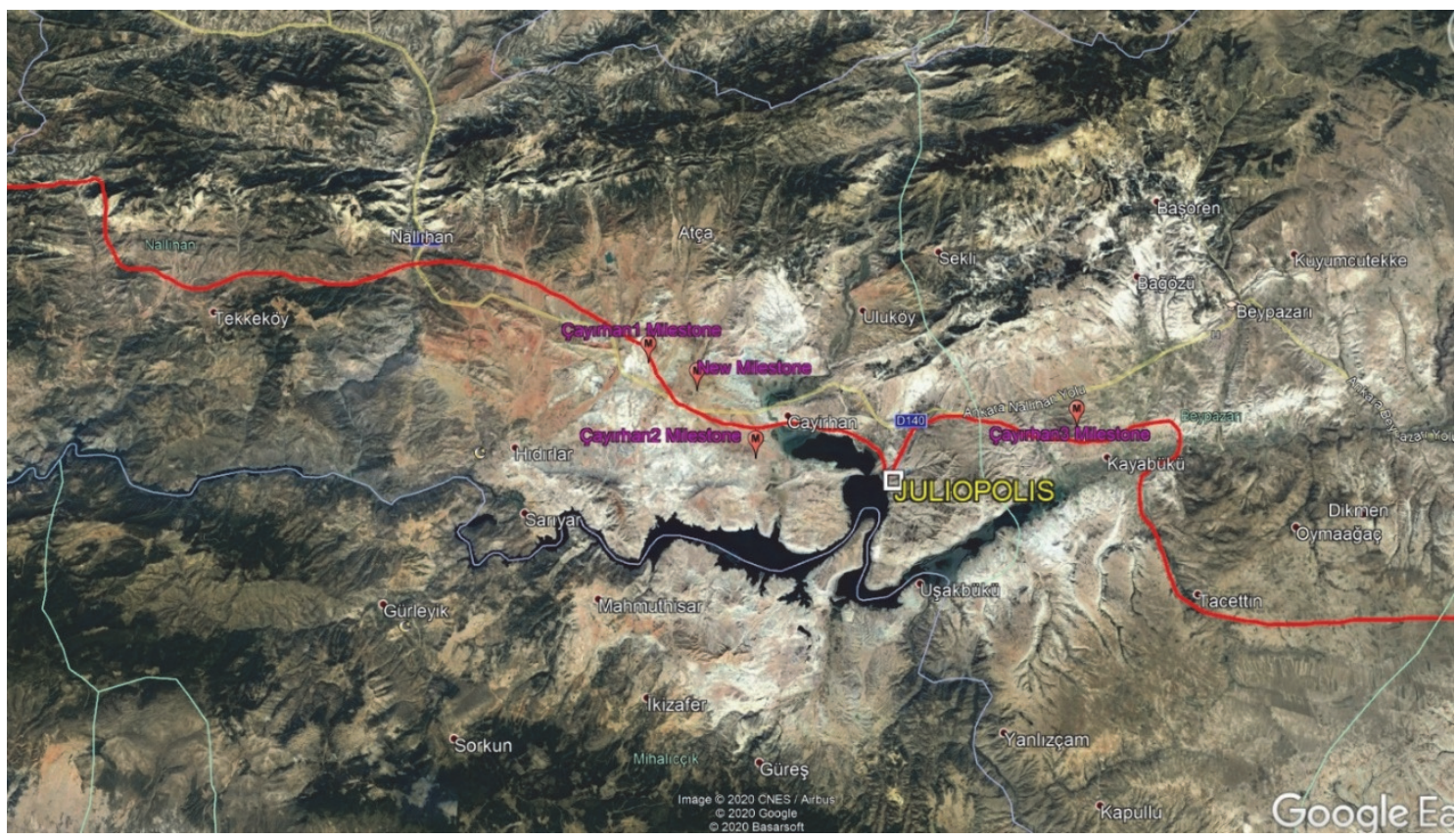

Fig. 1) The Milestones and Pilgrim's Road (Google Earth)

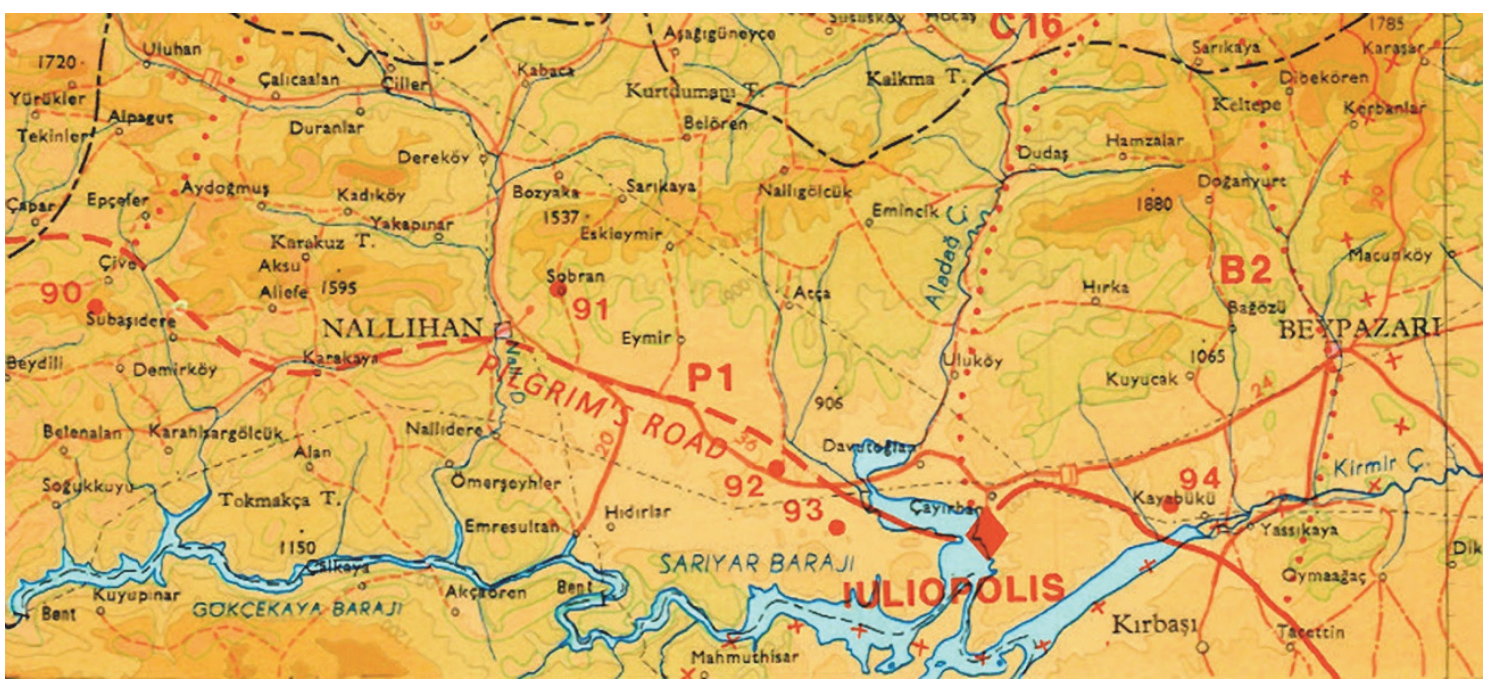

Fig. 2) The Pilgrim's Road and the milestones around Juliopolis

(base map: French 2016, 49, Pontus et Bithynia: 3.4.3 Zonguldak Sheet) 


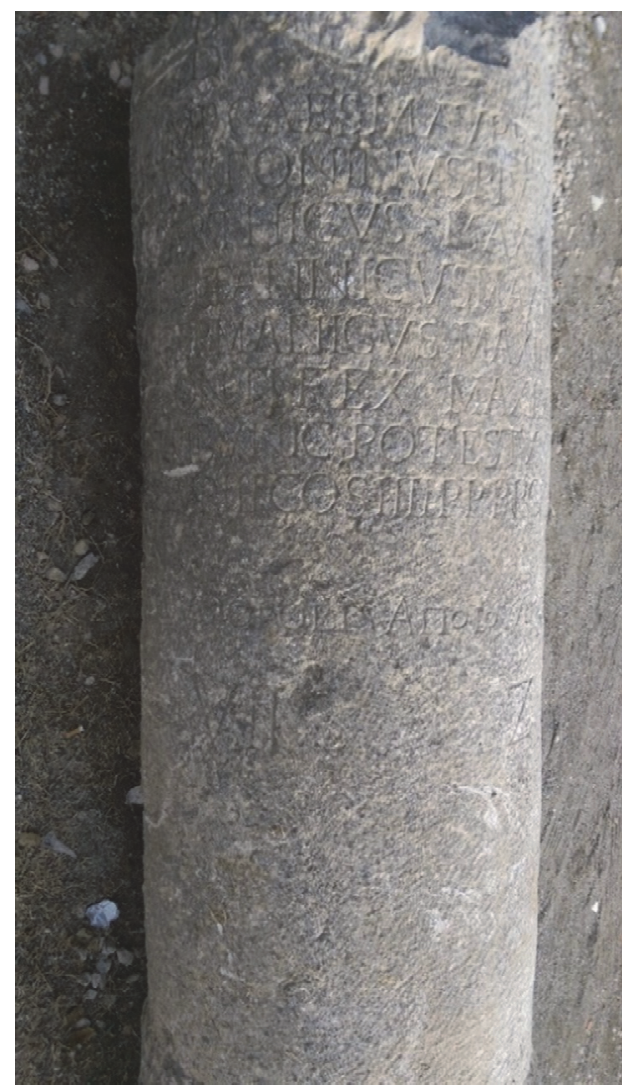

Fig. 3) No.1. Milestone from Caracallan Period

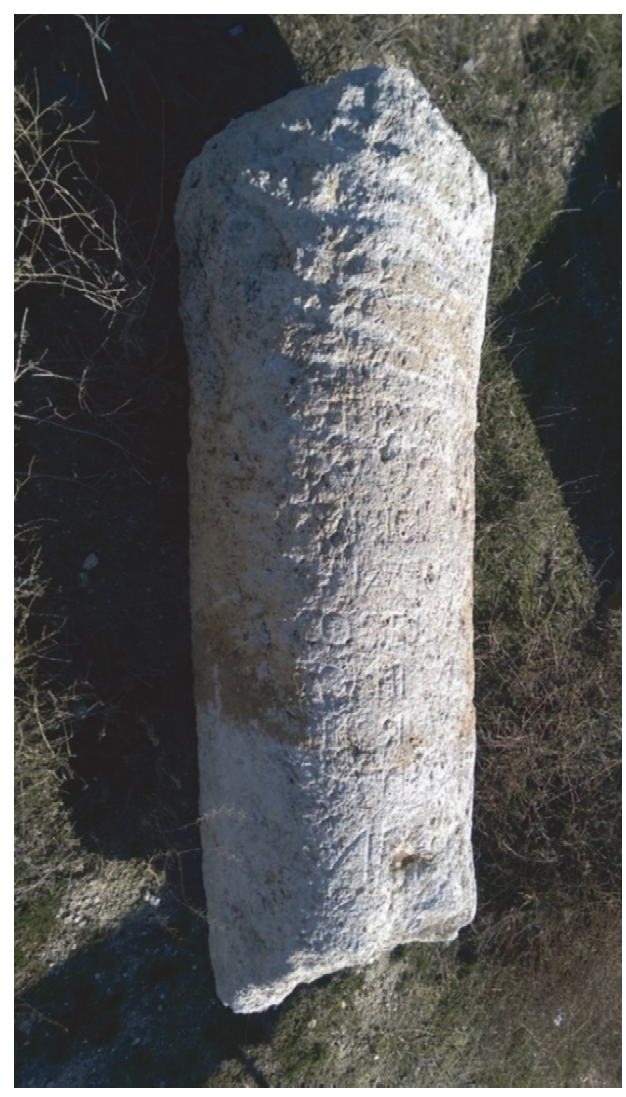

Fig. 5) No.2. Fragmentary Milestone

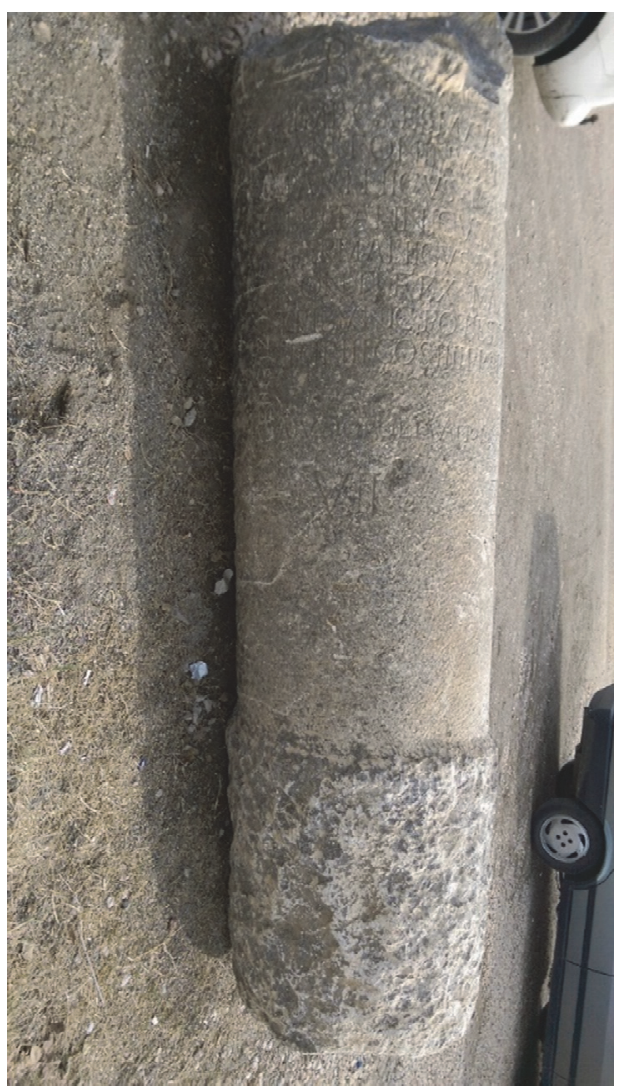

Fig. 4) No.1. Milestone from Caracallan Period

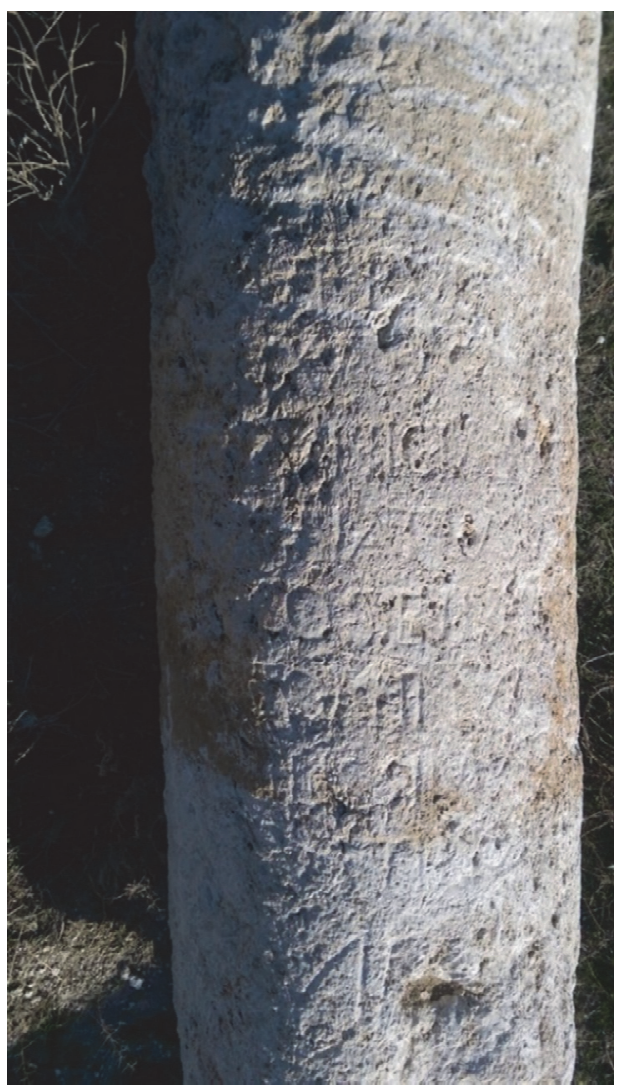

Fig. 6) No.2. Fragmentary Milestone 